\title{
Traditional farming and plant species diversity in agricultural landscapes of south-western Uganda
}

\author{
Gerald Eilu $^{\mathrm{a}, *}$, Joseph Obua ${ }^{\mathrm{a}}$, Joy K. Tumuhairwe ${ }^{\mathrm{b}}$, Charles Nkwine ${ }^{\mathrm{b}}$ \\ ${ }^{a}$ Department of Forest Biology and Ecosystems Management, Makerere University, P.O. Box 7062, Kampala, Uganda \\ ${ }^{\mathrm{b}}$ Department of Soil Science, Makerere University, P.O. Box 7062, Kampala, Uganda
}

Received 23 January 2002; received in revised form 19 March 2003; accepted 26 March 2003

\begin{abstract}
An effort was undertaken in Bushwere Parish (Mbarara district, south-western Uganda) between 1999 and 2000 to develop sustainable and participatory approaches to plant biodiversity conservation at the farm level. One hundred farmers were interviewed on their socio-economic profiles and plant use strategies. Plant diversity was assessed in 400 plots of $5 \mathrm{~m} \times 5 \mathrm{~m}$ established in 53 field types of seven land-use categories. The most species-rich land-use category was under annual crops (149 plant species) while the most species-rich field type was planted with bananas (118 species). Shannon diversity and Sørensen's similarity indices were used to compute species diversity and similarity, respectively, between field types and land-uses. The most plant diverse land-use was natural woodland, the least fallow. Canonical correspondence analysis (CCA) showed that occurrence of species, field type or land-use depended upon environmental factors such as elevation, position on the slope and soil type. Redundancy analysis (RDA) showed that species utility and occurrence were related to the socio-economic status of farmers. Plant species were most diverse in land-uses located on hill tops and steep slopes. Farmers should therefore be advised on how to maintain plant diversity in agricultural landscapes.
\end{abstract}

(c) 2003 Elsevier Science B.V. All rights reserved.

Keywords: Plant diversity; Agricultural landscape; Farming; Land-use; Field type

\section{Introduction}

Uganda's economy relies heavily on agriculture which contributes over $40 \%$ of the gross domestic product (GDP) and generates $90 \%$ of the foreign exchange earnings (NEMA, 1998). Apart from providing food security, agriculture supports the agro-industries and employs $86 \%$ of Uganda's 21 million people. Uganda has been divided into five farming system zones based on natural resource potential for agricul-

\footnotetext{
* Corresponding author. Tel.: +256-41-543647; fax: +256-41-533574.

E-mail addresses: eilu@forest.mak.ac.ug,eilug@yahoo.com (G. Eilu).
}

ture, social history and presence of tsetse flies, one of them the western Uganda banana-coffee-cattle farming system being the area of study.

Biodiversity conservation must include landscapes used for farming and pastoralism. Rural people use and manage biodiversity for sustainability of their livelihoods and for maintenance of natural and modified ecosystems. Biodiversity conservation on land used for agricultural purposes is one of the greatest challenges in the tropics where rapid population growth, unplanned settlement and fragmentation destroy fragile habitats and reduce plant species richness and abundance (NEMA, 2001).

As a prerequisite to developing practices for sustaining on-farm biodiversity in Uganda, the People, 
Land Management and Environmental Change (PLEC) project started a study in 1993 in Bushwere Parish, south-western Uganda to assess and teach sustainable and participatory approaches to plant biodiversity conservation at the farm level. PLEC was implemented by the Global Environment Facility (GEF) in conjunction with the United Nations University (UNU) and the United Nations Environment Programme (UNEP) as a collaborative effort between scientists and small-scale farmers from across the developing world. It is executed through a network of locally based clusters in West Africa, East Africa, AsiaPacific and South America. UNU/PLEC's outputs are geared towards influencing policy-making on agrodiversity conservation. Farmers and local communities involved in PLEC projects are encouraged to identify conservation strategies that are environmentally, socially, and financially sustainable while improving farm production and income. The present paper de- scribes an assessment of plant diversity and physical factors in relation to crop production, aimed at developing a set of sustainable agricultural technologies that maintain plant diversity in agricultural landscapes.

\section{Methods}

Bushwere Parish $\left(00^{\circ} 46^{\prime} \mathrm{S}\right.$ and $\left.30^{\circ} 32^{\prime} \mathrm{E}\right)$ covers an area of $31.6 \mathrm{~km}^{2}$ at altitudes ranging from 1200 to $1900 \mathrm{~m}$ above sea level. The landscape consists of a dissected plateau characterised by steep hills and long ridges with short $\mathrm{V}$-shaped valleys. The soils are ferralitic comprising dark brown gravel-loam (Kamugisha et al., 1997). Crop farming of mainly bananas, coffee, beans, peas, maize, potatoes, sweet potatoes, and pastoralism are the main activities.

The climate is 'modified tropical' with a mean annual rainfall of $700 \mathrm{~mm}$ with short rains in March-May

Table 1

Plant species richness in various field types of Bushwere Parish, south-western Uganda (1999-2000)

\begin{tabular}{|c|c|c|c|c|c|}
\hline Field type & Sample no. & Spp. no. & Field type & Sample no. & Spp. no. \\
\hline Mainly banana $(\mathrm{BaPu})$ & 8 & 118 & Millet-maize-banana-cassava & 7 & 26 \\
\hline Peas $(\mathrm{Pe})$ & 7 & 87 & Banana-beans-coffee & 8 & 23 \\
\hline Banana-beans & 7 & 73 & Maize & 7 & 21 \\
\hline Potatoes (Ip) & 7 & 71 & Sweet potatoes & 7 & 21 \\
\hline Beans-maize & 8 & 64 & Beans-fallow (BeFa) & 7 & 20 \\
\hline Maize-beans-cassava & 8 & 62 & Beans-maize-cassava & 8 & 20 \\
\hline Fallow & 7 & 60 & Maize-cassava-coffee & 8 & 20 \\
\hline $\begin{array}{l}\text { Combretum-Hyparrhenia-Cymbopogon } \\
\text { (CoHyCy) }\end{array}$ & 7 & 59 & Sweet potatoes-cassava & 7 & 19 \\
\hline Potatoes-maize & 8 & 53 & Hyparrhenia-grassland & 7 & 18 \\
\hline Maize-beans & 8 & 53 & Bananas-coffee-cassava & 8 & 16 \\
\hline Sorghum-maize & 7 & 52 & Maize-sorghum & 8 & 16 \\
\hline Loudetia-Hyparrhenia (LoHyGr) & 7 & 51 & Beans-maize-potatoes & 8 & 15 \\
\hline Potatoes-maize-beans & 8 & 49 & Fallow-sweet potatoes $(\mathrm{FaSp})$ & 7 & 15 \\
\hline Cymbopogon-Hyparrhenia (CyHyGr) & 7 & 47 & Peas-beans $(\mathrm{PeBe})$ & 8 & 15 \\
\hline Pteridium-Combretum ( $\mathrm{PtCo})$ & 7 & 47 & Beans-cassava (BeCa) & 8 & 14 \\
\hline Beans-cassava-maize & 8 & 45 & Potatoes-cassava & 8 & 14 \\
\hline Millet-maize & 8 & 42 & Gr. nuts-sweet potatoes-cassava ( $\mathrm{GnSpCa})$ & 7 & 13 \\
\hline Beans $(\mathrm{Be})$ & 7 & 36 & Sweet potatoes-bananas & 8 & 13 \\
\hline Wooded savanna (Ws) & 7 & 35 & Bananas-maize-beans & 8 & 12 \\
\hline Banana-beans-maize-coffee & 8 & 33 & Beans-bananas & 8 & 12 \\
\hline Cymbopogon-Loudetia & 7 & 33 & Potatoes-beans (IpBe) & 8 & 11 \\
\hline Banana-coffee (BaCo) & 8 & 31 & Maize-beans-fallow (MaBeFa) & 7 & 11 \\
\hline Potatoes-sweet potatoes-maize & 7 & 31 & Maize-potatoes & 8 & 9 \\
\hline Cassava $(\mathrm{Ca})$ & 7 & 30 & Beans-potatoes (BeIp) & 8 & 8 \\
\hline Cassava-millet-maize & 8 & 28 & Beans-potatoes-maize & 8 & 8 \\
\hline Cassava-peas (CaPe) & 8 & 28 & Potatoes-beans-maize & 7 & 6 \\
\hline Maize-millet & 8 & 28 & & & \\
\hline
\end{tabular}


Table 2

Shannon diversity index for seven land-use categories in Bushwere Parish, south-western Uganda (1999-2000)

\begin{tabular}{lcc}
\hline Land-use category & $\begin{array}{l}\text { Number of } \\
\text { samples } \\
\text { considered }\end{array}$ & $\begin{array}{l}\text { Diversity } \\
\text { index }\left(H^{\prime}\right)\end{array}$ \\
\hline Natural woodland (NatWoo) & 21 & 3.448 \\
Natural grassland (NatGra) & 28 & 2.961 \\
Mainly banana (BanPla) & 78 & 2.667 \\
Annual crops (AnnCro) & 245 & 2.585 \\
Fallow & 7 & 1.911 \\
Annual crops with some & 14 & 0.913 \\
$\quad$ fallow (AnCrFa) & 7 & 0.565 \\
Fallow with some annual & & \\
$\quad$ crops (FaAnCr) & & \\
\hline
\end{tabular}

and long rains in August-November. Average minimum and maximum temperatures are 20.2 and $32^{\circ} \mathrm{C}$. The vegetation is mainly wooded savanna dominated by Acacia, Combretum and Albizia trees, and Cymbopogon, Hyparrhenia, Kyllinga, Sporobolus and Themeda grasses. The average population density is 200-249 persons $/ \mathrm{km}^{2}$ (Government of Uganda, 1992).

Bushwere Parish was visited during the major (August-November 1999) and minor (March-May 2000) growing season to capture temporal variation in plant species diversity. Four villages (the smallest local administrative unit) of similar area and population were included in the study. In each village we selected 7-245 samples of seven land-use categories: (1) annual crops with some fallow (AnCrFa), (2) annual crops (AnnCro), (3) mainly banana (BanPla), (4) fallow with some annual crops (FaAnCr), (5) fallow only $(\mathrm{Fa}),(6)$ natural grassland (NatGra) and (7) natural woodland (NatWoo). A total of 53 field types (managed sections of fallow or forest, trees on farm, agro-forests and orchards) with specific farming practices or plant cover (refer to Brookfield et al., 1999) were identified (Table 1). In each village, gardens (a homogeneous portion owned by an individual farmer) per field type was selected. Each garden was divided diagonally into four approximately equal sub-units. At the centre of each sub-unit, one $5 \mathrm{~m} \times 5 \mathrm{~m}$ plot was marked with stakes and flagging tape, and each plot was divided into 25 quadrats or samples of $1 \mathrm{~m} \times 1 \mathrm{~m}$. Four such quadrats per garden (or 7-8 samples per field type) were randomly selected for detailed plant species inventories (Zarin et al., 1999). Total number of plant species, species diversity, soil types (as identified by farmers), and position in the landscape were recorded in each garden. In addition, 100 farmers

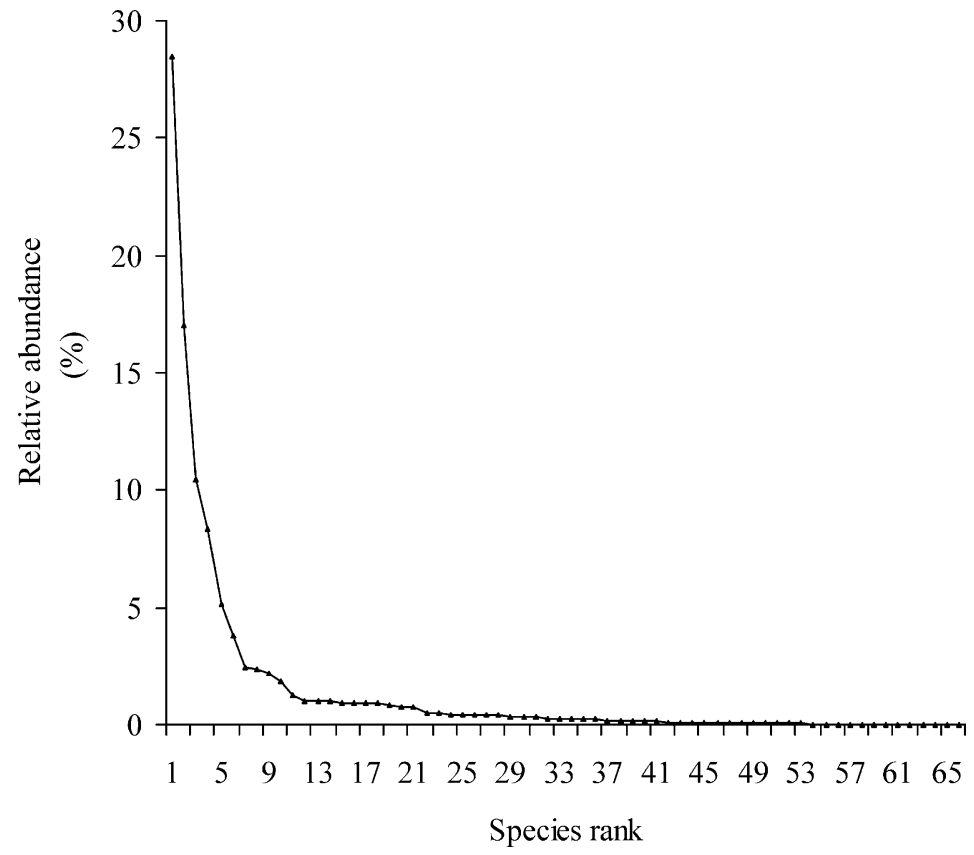

Fig. 1. Diversity curve for plant species occurring in mainly banana field type ( $n=118$ species). 
were interviewed on their socio-economic profile and plant species utilisation.

Plant diversity was computed using Shannon diversity index $H^{\prime}=-\sum p_{i} \ln p_{i}$, where $p_{i}=$ proportional abundance of species $i\left(n_{i} / N\right)$. Multivariate statistical package was used to carry out a cluster analysis based on Sørenson's similarity index (Zarin et al., 1999); $\left(S_{\mathrm{s}}=2 T_{\mathrm{ci} j} j /\left(T_{i}+T_{j}\right)\right.$, where
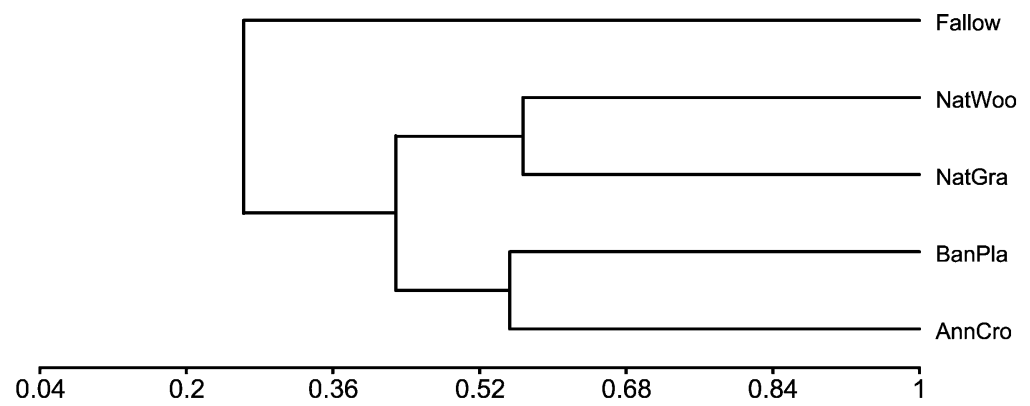

(a)

Sorensen's Coefficient

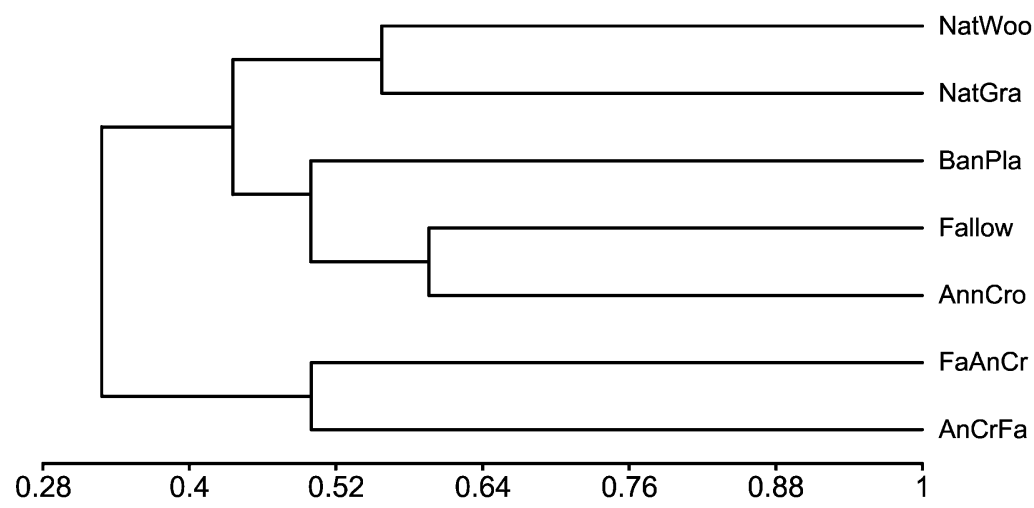

(b)

Sorensen's Coefficient

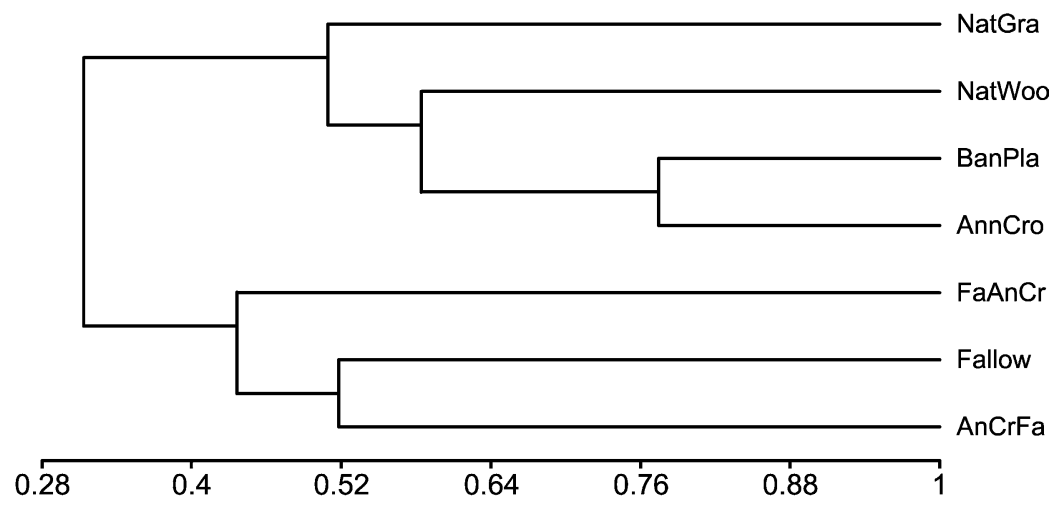

(c)

Sorensen's Coefficient

Fig. 2. Vegetation similarity between land-use categories based on Sørensen's similarity index (Uganda): (a) major growing season in 1999; (b) minor growing season in 2000; (c) pooled data (abbreviations cf. Table 2). 
$T_{i}$ and $T_{j}$ are number of species occurring in sample units $i$ and $j$, respectively, and $T_{i \& j}$ the number of species common to sample units $i$ and $j$ ). Canonical correspondence analysis (CCA), that combines aspects of direct gradient analysis (regression) and indirect gradient analysis based on a unimodal model (ordination), was performed using CANOCO to show the relationship between field types, land-uses and environmental factors. Redundancy analysis (RDA), based on a linear model, was used to show the relationship between plant species utilisation and socio-economic characteristics of the farmers.

\section{Results}

Species richness varied between extremely speciespoor (one species on average) and species-rich plots
(24.5 species per plot). The species-richest field types were associated with bananas, peas and potatoes, the species-poorest field types with maize-bean mixed cropping (Table 1). Species richness by land-use was highest in the annual crop (149 species) followed by mainly banana (143), natural woodland (87), natural grassland (80), fallow only (60), annual crop with some fallow (25), and fallow with some annual crops (15). Natural woodland had the highest species diversity followed by natural grassland, all land-uses based on fallow had the lowest (Table 2).

Of 211 plant taxa recorded in Bushwere Parish, $3.3 \%$ occurred in all land-uses, the most common species being Bidens grantii (Oliv.) Sherff, Bidens pilosa L., Commelina benghalensis L., Conyza floribunda H.B.K. and Phyllanthus capillaris Schum. \& Thonn. Some $21 \%$ of the species occurred in 4-6 land-use categories, one-third of them in only one.

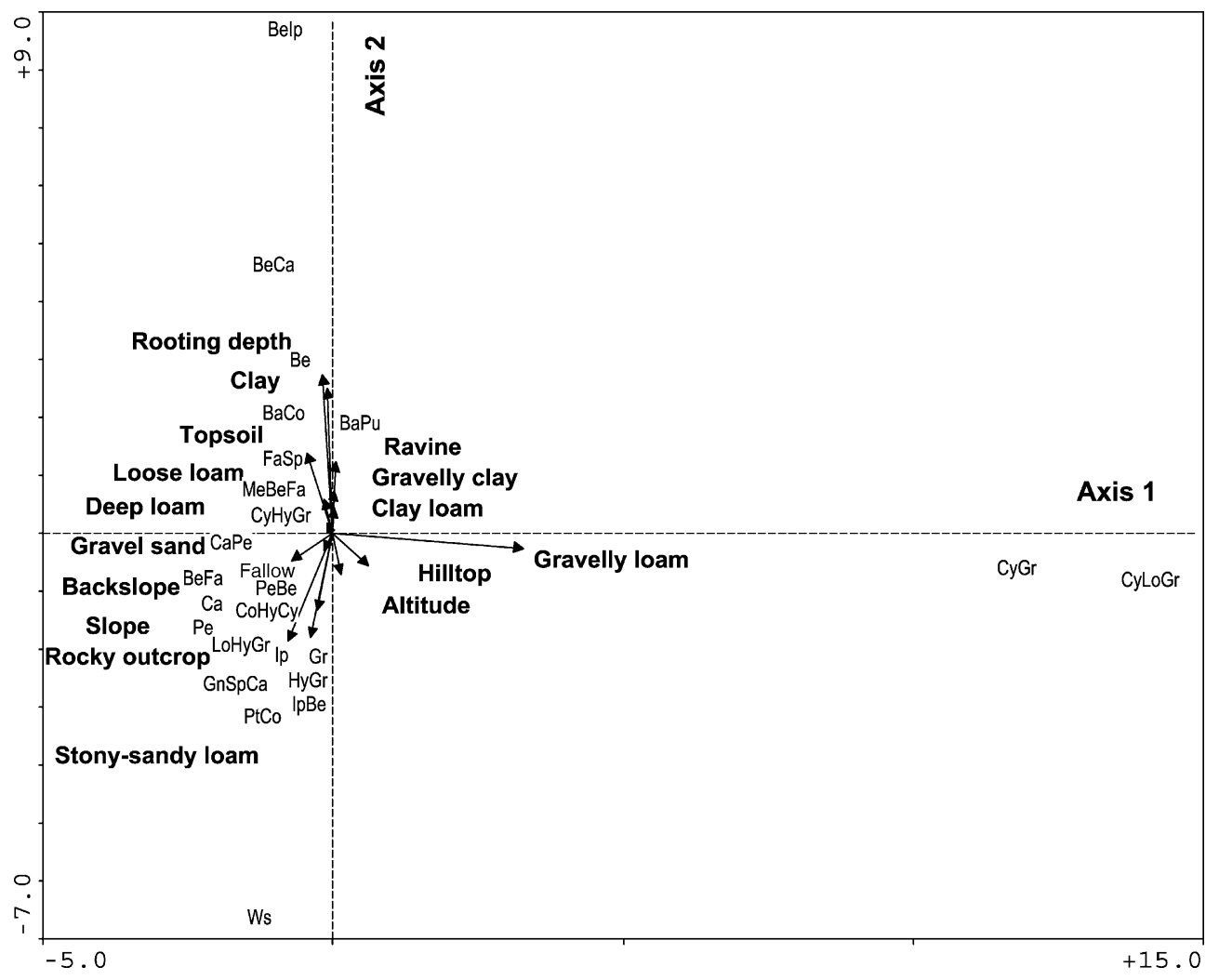

Fig. 3. CCA ordination of field types according to environmental factors. Field types and land-uses appear in smaller font size and arrows indicate the environmental factors (abbreviations cf. Tables 1 and 2). 
The abundance-diversity curve for the mainly banana field type is presented in Fig. 1, all other field types exhibiting similar trends.

Similarity coefficients for plant species occurring in various field types ranged from 0.317 to 0.882 . The field-type banana-beans had the most homogeneous species composition. Natural woodland and natural grassland were most similar in terms of plant species (similarity coefficient $=0.568$ ), both in the major (Fig. 2(a)) and minor growing season differing most from other land-uses in the major growing season. Annual crop and fallow were most similar in the minor growing season followed by natural woodland and natural grassland (Fig. 2(b)). When data were pooled (Fig. 2(c)), annual crop and mainly banana were the most similar land-uses. Interestingly, land-uses based on fallow formed a cluster which differed from all the other land-uses.

According to colour and texture, farmers distinguished the following soil types: clay, clay-loam, deep loam, loose loam, gravelly loam, stony-sandy loam, gravelly-clay, and rocky outcrop. Ordination of field types, land-uses and environmental factors revealed (Fig. 3) that the Cymbopogon-grassland and the Cymbopogon-Loudetia-grassland occurred on mainly gravelly loam soils. Based on the eigenvalue of 0.703 , Axes 1 and 2 of the ordination diagram explained $7.2 \%$ of the variance within field types. Axes $1-4$ (eigenvalue $=0.571$ ), explained $34.4 \%$ of the variance in weighted-averages and class totals of the field type-environmental factors relation. Most of the variance was explained by the soil type that had

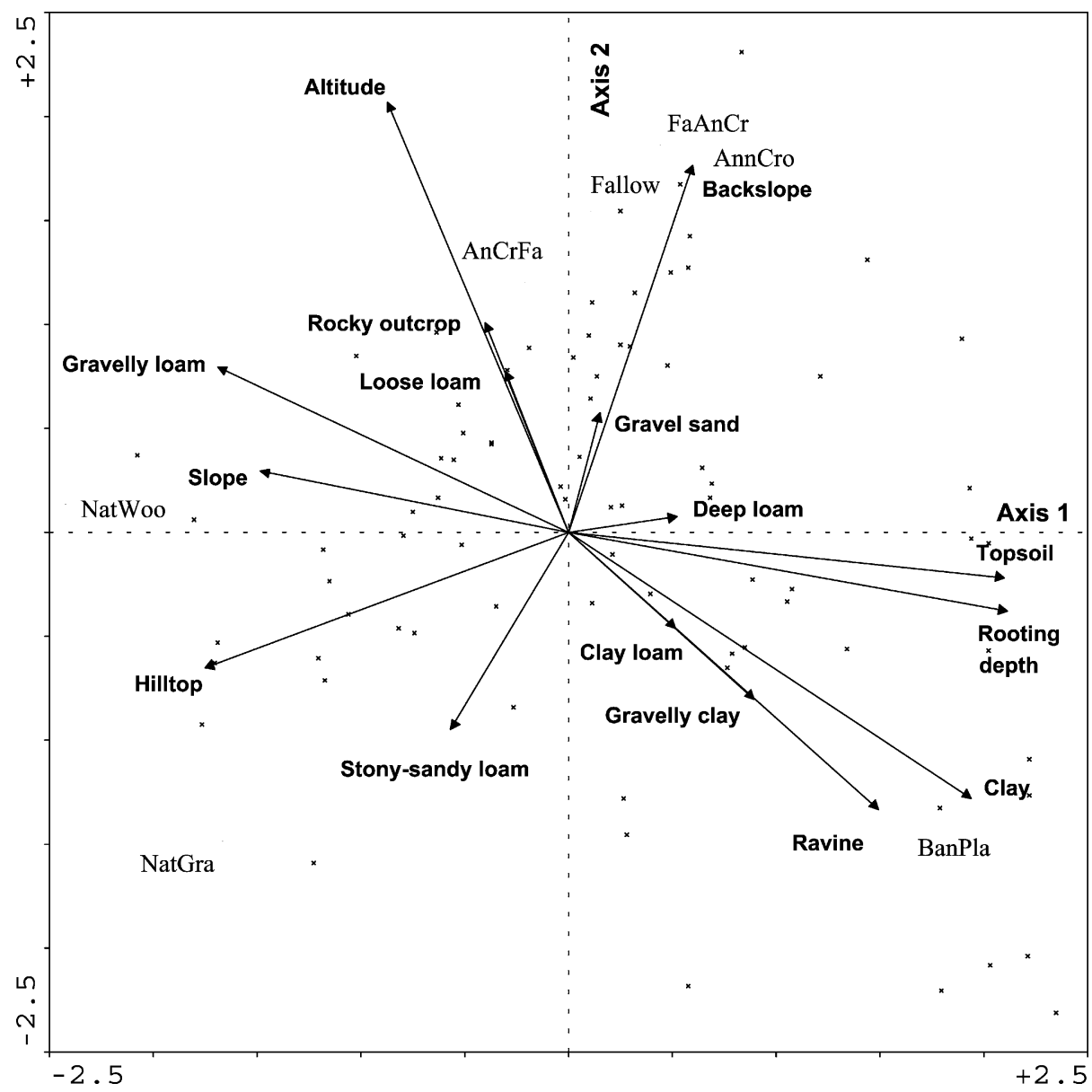

Fig. 4. CCA ordination of land-uses (smaller font) according to environmental factors (arrows). 
the longest arrow almost parallel to Axis 1 (gravelly loam). Other soil types did not influence the distribution of species in field types considerably.

Fig. 4 shows that natural grasslands and natural woodlands were mainly on hilltops and steep slopes, and banana plantations on ravines. Fig. 5 shows the ordination of environmental factors and plant species. The first and second CCA axes displayed in the ordination diagram (eigenvalues 0.658 and 0.534 , respectively), explained $11.4 \%$ of the variance in plant species data, and $42.7 \%$ of the variance in the plant species-environment relation. The four axes explained $16.5 \%$ of the variance in species data, and $62.2 \%$ of the variance in the relation between species and environmental factors. Altitude, top-soil and one soil type (loose loam) mostly influenced the distribution of plant species.
According to the interviewed farmers, 120 plant species were commonly used for food (20\%), medicine $(20 \%)$, craft $(7 \%)$, grazing $(4 \%)$, construction $(3 \%)$, brewing $(2 \%)$, commerce $(2 \%)$, proping $(1 \%)$ and cultural purposes (1\%). Dracaena fragrans (L.) Ker Gawl. used for crafts was sold for cash, Acanthus pubescens Engl. was used for staking or proping. Species such as Albizia spp. and Eucalyptus spp. were used for construction, Momordica foetida Schumach for cultural purposes during rituals. Agricultural crops, weeds and wild species were eaten. Introduced species such as Physalis peruviana L. whose fruits are sold in the market were spared during cultivation. Other food plants were Leonotis nepetifolia (L.) Ait. f., Dioscorea alata L., Asystasia gangetica (L.) T. Anders., Coffea canephora Froehner, Rhus vulgaris Meikle and Solanum nigrum L. Pan-tropical weeds

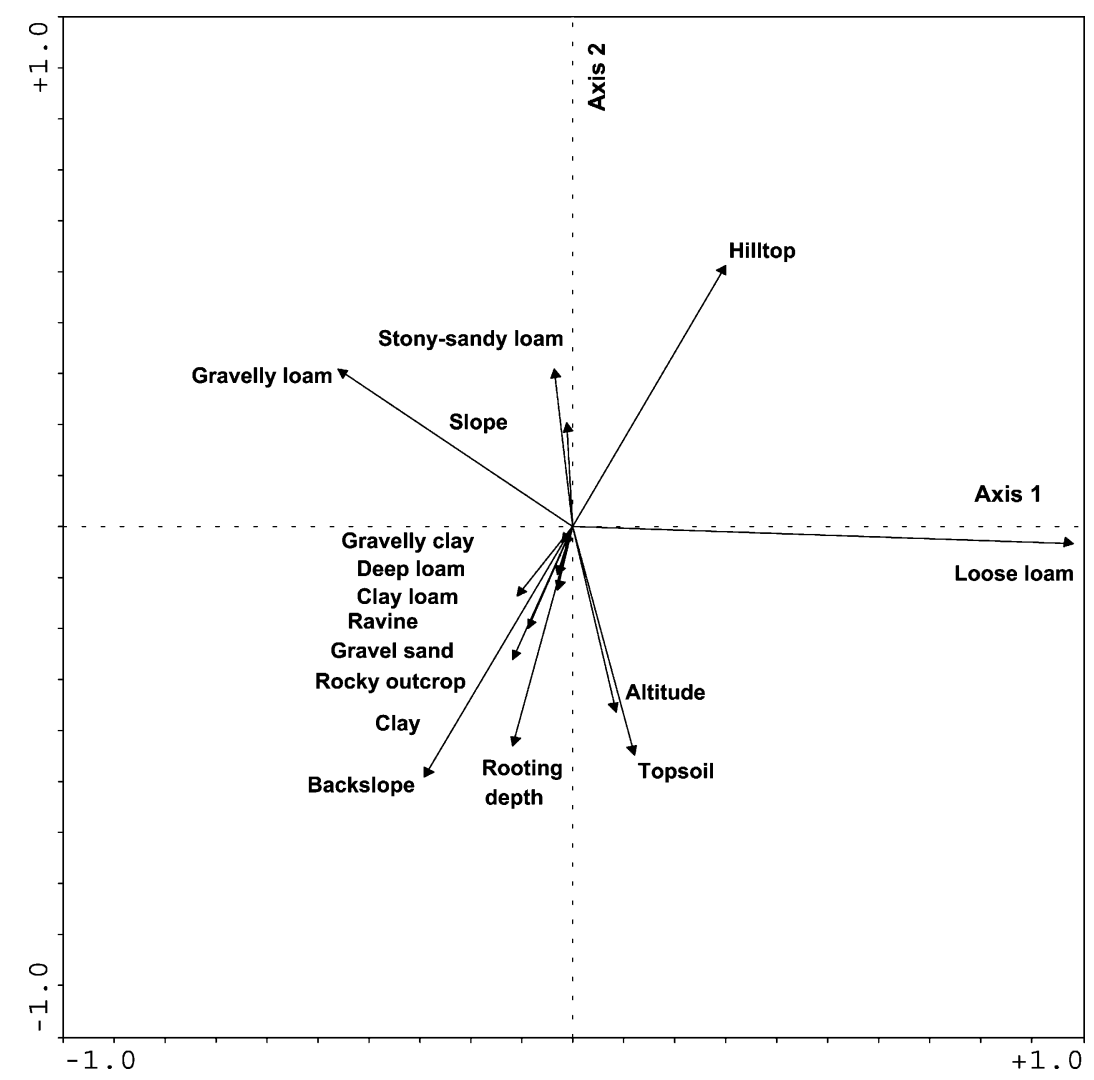

Fig. 5. CCA ordination of species and environmental factors (arrows). Species names have been deleted from the ordination diagram for clarity. 


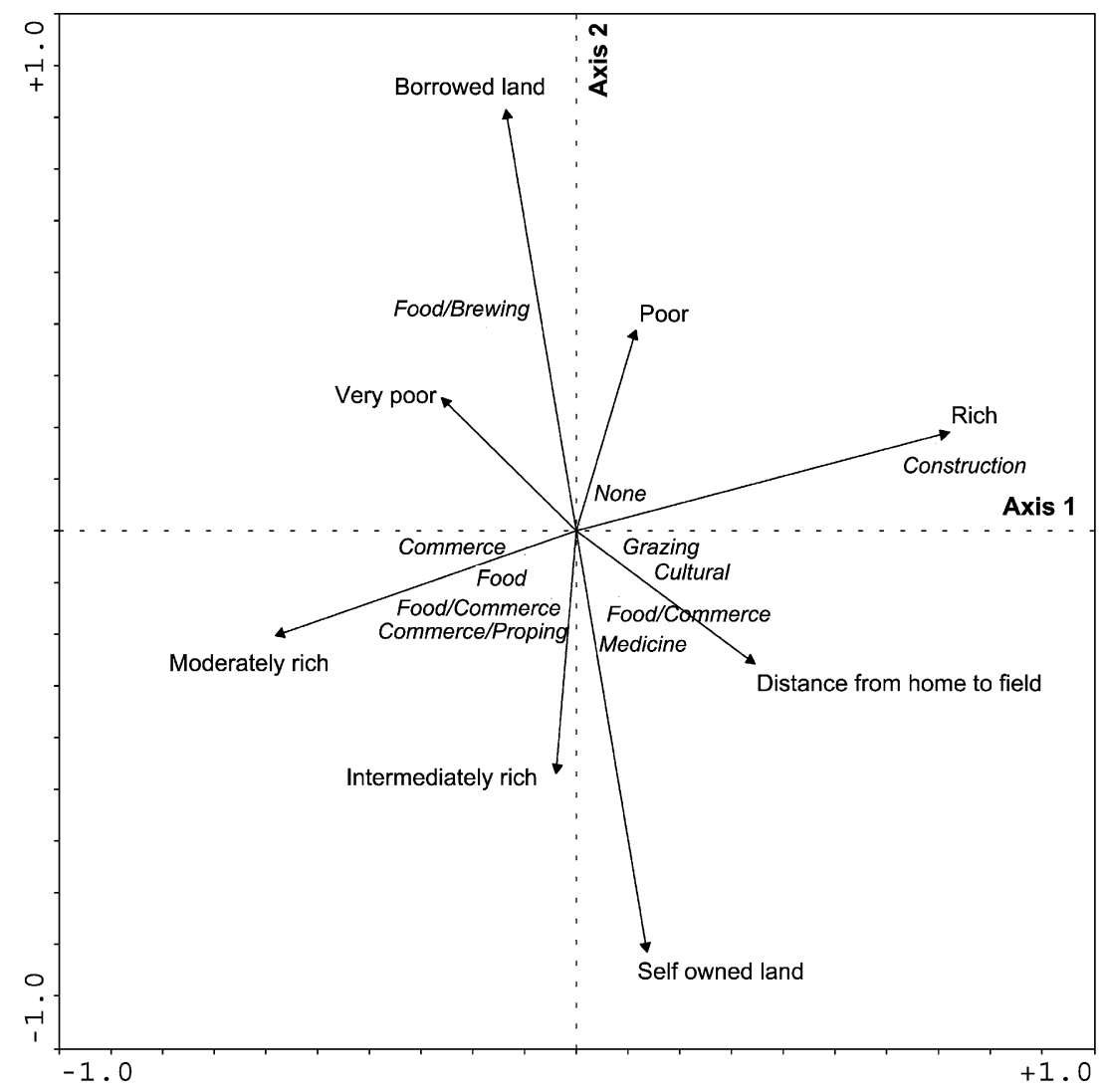

Fig. 6. RDA of species utility and socio-economic factors of farmers in Bushwere Parish, south-western Uganda.

such as Amaranthus dubius Thell., A. graecizans L., A. hybridus L. and A. lividus L. were spared on the farms and their leaves or shoots eaten. Eleusine coracana L. and Musa paradisiaca L. were eaten or sold for cash, Acacia abyssinica [Hochst.ex]Benth, Chloris gayana Kunth, Indigofera spicata Forsk., Panicum maximum Jacq., Setaria sphacelata (Schumach) and Vigna unguiculata (L.) Walp. were spared for fodder. Species such as Catha edulis (Vahl) Endl., Clutia abyssinica Jaub. \& Spach, Capparis tomentosa Lam., Commelina africana L., C. benghalensis L., Crassocephalum crepidiodes (Benth.) S. Moore, $C$. vitellinum (Benth.) S. Moore, Emilia coccinia (Sims) G. Don, Erythrina abyssinica DC, Hibiscus fuscus Garcke, Rubia cordifolia L. and Vernonia amygdalina Del. were spared for medicine. V. amygdalina was used to treat malaria and Crassocephalum spp. to treat snake-bites. Firewood and craft materials were obtained from Combretum spp. found in the wood- lands and forest. Only $41 \%$ of the plant species had no recognised use.

Ordination of species utility and farmers' socioeconomic profile is shown in Fig. 6. Axis 1 and 2 explained $78 \%$ of the relationship whilst the four axes explained 94\%. Farmers who owned land far from home exploited the immediate neighbourhood for food and medicine. Relatively rich farmers depended less on wild plants as the main source of livelihood except for construction materials. Poor farmers and squatters harvesting plants for food, medicine and local beer brewing could take part in future programmes targeted at plant conservation in agricultural landscapes.

\section{Discussion and conclusions}

Local communities living in the rural areas of developing countries usually depend on plant resources in 
the agricultural landscapes that are also used for crop growing and livestock rearing. According to Bekunda and Woomer (1996) land management by resource poor farmers is often characterised by application of crop residues to maintain soil fertility and crop production. This is common in the banana-based cropping system where farmers incorporate banana stalks and other crop residues into the soil. Banana cultivation under organic practices improves soil fertility, supports more plant species and should be encouraged. Small farmers usually own small portions of land where large-scale farming is not viable. Although large-scale systems may produce high yields in the short term, they require agro-chemicals that are not encouraged and increasingly rejected by the market. Also, plant conservation under large-scale farming is limited because of the mechanised nature of farming and the monocultures involved.

The effects of environmental factors on plant species distribution are poorly known in Uganda (Langdale-Brown et al., 1964). Sanchez et al. (1989) linked crop cultivation in tropical ecosystems with the distribution of plant species on soils of low fertility. In Bushwere Parish, indigenous plant species that occurred in only one or two land-uses need to be preserved when harvested and used by the local people. Otto et al. (1995) noted that one of the major challenges in plant conservation was to identify species that merit conservation.

Short fallow and vegetation clearing will affect occurrence, distribution and richness of plant species in south-western Uganda. The current farming system degrades the soils and results in species-poor fields. It might be desirable to increase the fallow periods (Joyotee et al., 1999) so that degraded sites can revert to the original vegetation. The expansion of fallow and grasslands that are more species-rich should be encouraged, perhaps through subsidising organic fertilisers and extension services (Joyotee et al., 1999).

The primary threat to natural ecosystems has always been intensive agricultural production (Given, 1994), affecting particularly sites that are easily degraded on relatively fertile soils. The plant species that tend to survive in poor sites may, therefore, be well represented in a fragmented agricultural landscape as opposed to those that prefer more fertile sites.

The ordination of environmental factors, showed that farmers' knowledge of environmental factors was important for the development of local soil conservation and should be encouraged. In Zambia, local knowledge of soils has been used by farmers to select crops that are suitable for particular areas (Posey et al., 1999) and to develop land management practices that minimise the loss of plant diversity. Resource poor farmers spared plants that were of socio-economic value during cultivation. This practice should be encouraged and the extension service under the Uganda National Agricultural Advisory Services (NAADS) should focus on guiding farmers to develop environmentally sound farming, on-farm tree planting, and maintaining field types that best satisfy their socio-economic needs.

\section{Acknowledgements}

We thank the People, Land Management and Environmental Change (PLEC) Project for supporting the fieldwork. The Department of Soil Science is acknowledged for facilitating data collection and analysis. We are indebted to the farmers who participated in the study that was undertaken as part of PLEC's project in Uganda. We also thank the two anonymous reviewers for their comments on the earlier version of the manuscript.

\section{References}

Bekunda, M.A., Woomer, P., 1996. Organic resource management in banana-based cropping systems of Lake Victoria Basin, Uganda. Agric. Ecosyst. Environ. 59, 171-180.

Brookfield, H., Stocking, M., Brookfield, M., 1999. Guidelines on agrodiversity assessment in demonstration site areas. PLEC News Views 13, 17-31.

Given, D.R., 1994. Principles and Practice of Plant Conservation. Timber Press, Portland, OR, 292 pp.

Government of Uganda, 1992. Ministry of Finance and Economic Planning: Background to the Budget. Government Printing and Publishing Corporation, Entebbe.

Joyotee, S., van de Kop, P., Reategui, K., Lombardi, I., Sabogal, C., Diaz, A., 1999. Dynamics of secondary forests in slash-and-burn farming: interactions among land use types in the Peruvian Amazon. Agric. Ecosyst. Environ. 76, 85-98.

Kamugisha, J.R., Ogutu, Z.A., Stahl, 1997. Parks and PeopleConservation and Livelihoods at Crossroads. SIDA Regional Soil Conservation Unit, Nairobi, 109 pp.

Langdale-Brown, I., Osmaston, H.A., Wilson, J.G., 1964. The Vegetation of Uganda and its Bearing on Land Use. Government Printer, Entebbe, 159 pp. 
NEMA, 1998. State of the Environment Report for Uganda. National Environment Management Authority, Ministry of Environment and Natural Resources, Kampala, 239 pp.

NEMA, 2001. State of the Environment Report for Uganda. National Environment Management Authority, Ministry of Water Lands and Environment, Kampala, 153 pp.

Otto, H.F., Brown, A.H.D., Burdon, J.J., 1995. The Conservation of Plant Biodiversity. Cambridge University Press, Cambridge, 299 pp.

Posey, D.A., Oxford Centre for Environment, Ethics and Society, Mansfield College, 1999. Cultural and spiritual values of biodiversity. A complementary contribution to the global biodiversity assessment. United Nations Environment Programme, Nairobi, 731 pp.

Sanchez, P.A., Palm, C.A., Szott, L.T., Cuevas, E., Lal, R., 1989. Organic input management in tropical ecosystems. In: Coleman, D.C., Oades, J.M., Uehara, G. (Eds.), Dynamics of Soil Organic Matter in Tropical Ecosystems. NifTal Project, Paia, Hawaii, USA, pp. 125-152.

Zarin, D.J., Guo, H., Enu-Kwesi, L., 1999. Methods for the assessment of plant species diversity in complex agricultural landscapes: guidelines for data collection and analysis from the PLEC Biodiversity Advisory Group. PLEC News Views 13, $3-16$. 